\title{
GCU
}

Glasgow Caledonian

University

University for the Common Good

\section{Participation: add-on or core component of public service delivery?}

Osborne, Stephen P.; Strokosch, Kirsty

Published in:

Australian Journal of Public Administration

DOI:

10.1111/1467-8500.12536

Publication date:

2022

Document Version

Publisher's PDF, also known as Version of record

Link to publication in ResearchOnline

Citation for published version (Harvard):

Osborne, SP \& Strokosch, K 2022, 'Participation: add-on or core component of public service delivery?',

Australian Journal of Public Administration, vol. 81, no. 1, pp. 181-200. https://doi.org/10.1111/1467-8500.12536

\section{General rights}

Copyright and moral rights for the publications made accessible in the public portal are retained by the authors and/or other copyright owners and it is a condition of accessing publications that users recognise and abide by the legal requirements associated with these rights.

Take down policy

If you believe that this document breaches copyright please view our takedown policy at https://edshare.gcu.ac.uk/id/eprint/5179 for details of how to contact us. 


\section{Participation: Add-on or core component of public service delivery?}

\section{Stephen P. Osborne ${ }^{1} \quad$ Kirsty Strokosch ${ }^{2}$ (i)}

\author{
${ }^{1}$ Centre for Service Excellence (CenSE), \\ University of Edinburgh Business School, \\ Edinburgh, UK \\ ${ }^{2}$ Glasgow Caledonian University \\ Business School, Glasgow, Scotland, UK

\section{Correspondence} \\ Professor Stephen Osborne, Centre for \\ Service Excellence (CenSE), University of \\ Edinburgh Business School, Edinburgh \\ EH8 9JS, Scotland, UK. \\ Email: stephen.osborne@ed.ac.uk
}

\begin{abstract}
Drawing on a systematic review of the literature, this paper explores the factors which have enabled and/or constrained the transformative potential of public service user participation within the five most influential recent narratives of public service reform. It argues that these narratives have failed either to offer a holistic conceptualisation of such participation in theory or to achieve its enactment in practice for four main reasons: participation is framed as polemic, with limited evidence of efficacy; public service delivery has been conceptualised as a linear process, with participation at its margins; structural changes have been insufficient in embedding participation; and power asymmetries have been reinforced through successive reforms. To combat these long-standing challenges, a value-creation approach is presented, which starts from an assumption of participation as a defining feature of public service delivery and considered how its import can be maximised to create value for individuals and society.

\section{KEYWORDS}

participation, public service reform, service delivery, value and value-creation
\end{abstract}

\footnotetext{
This is an open access article under the terms of the Creative Commons Attribution-NonCommercial-NoDerivs License, which permits use and distribution in any medium, provided the original work is properly cited, the use is non-commercial and no modifications or adaptations are made.

(C) 2021 The Authors. Australian Journal of Public Administration published by John Wiley \& Sons Australia, Ltd on behalf of Institute of Public Administration Australia.
} 


\section{1 | INTRODUCTION}

This paper is based on a systematic review of the public administration and management (PAM) literature. It explores how public service user participation has been framed and evolved within the five most influential narratives of public service reform of recent times-New Public Administration (NPA), New Public Management (NPM), Public Value (PV), New Public Service (NPS) and New Public Governance (NPG). The paper explores the extent to which these narratives argue for participation as a mechanism through which to open up both PAM theory and the practice of public service delivery to greater participation, and what important benefits they argue will ensue from such participation. However, despite the proposed advantages and the range of variants of participation across the narratives, we find that in practice, and despite a plethora of rhetoric, participation has continued to be a chimera, consigned at best to the periphery of public service production (Strokosch \& Osborne, 2020b).

Subsequently, an alternative theoretical narrative will be proposed that integrates citizen participation with value creation through public service delivery. This emphasises participation not as an add-on or normative element of public service delivery but as a core component part of public service delivery, where the end user plays a central role in value creation for themselves and for society. The purpose of this contribution is not to disregard previous narratives, but rather to build on and supplement the PAM literature and offer a more holistic understanding of how citizens participate in public service delivery and the implications for value creation.

\section{1 | Three caveats}

First, the focus in this paper is explicitly on participation in the delivery of public services rather than upon participation in the public policymaking process(es) for public services. To an extent this is an artificial distinction. Policymaking and public service delivery are two parts of the same process: policymaking is meaningless in itself if it does not lead to changes in actual public service delivery whilst one cannot make sense of the delivery of public services without understanding the policy context within which they exist. Having said that, participation in policymaking and in public service delivery do possess different valances.

Participation in the policymaking process is primarily an issue of democracy and the democratisation of the public policy process (Michels \& de Graf, 2010). This approach has a long history, from the seminal paper of Alford and Friedland (1975) through the more recent studies of open government in a digital age (Wirz et al., 2019).

These concerns are not unimportant when exploring citizen participation in the delivery of public services. However, the weight of this latter strand of evaluation is more towards the impact of participation both upon the transparency and legitimacy of public services and upon their effectiveness in addressing societal and economic need (Pestoff, 2014). Studies of participation in policymaking and in public service delivery are both concerned with the impact of power on public services, but the former explores this within the political context of democratisation, whereas the latter explores it within the need for accountable and responsive public services.

This is not a rigid distinction of course, as Turnhout et al. (2020) have revealed in the context of co-production in environmental policy and services. Further, as demonstrated below, both the NPA and the NPS discourses attempted to integrate both the policymaking and public service delivery foci for participation. However, the prime focus of this paper is upon citizen and user involvement in the delivery of public services and the import and impact of this involvement for 
the delivery of public services. Finally, a key task in the social sciences is often the disaggregation and analysis of clustered concepts before their reintegration into a more unified theory (Shoemaker et al., 2004). This paper is devoted to the first of these tasks. It seeks to disaggregate the components of participation in public service delivery. A subsequent task is their reintegration with participation in the public policymaking process.

Second, the discussion in this paper is at the most general level of public service provision. It is true, though, that public services cover a wide continuum of services including, inter alia, social and health care, education, parks maintenance, and the administration of the taxation and welfare benefit systems. The mechanisms of these different public services, and the import of participation within them, will vary. This is an important direction of future research. However, the focus here is upon the extent to which participation has been embedded as a core element of the meta-level discourses of public service reform and the evidence about their impact.

Third, the intent here is not to suggest that public service organisations (PSOs) are wholly normative and with an inherent redistributive intent. Indeed, there is a substantial literature that explores how, for example, power imbalances or elite capture can impact such apparently redistributive mechanisms as co-production (e.g. Farr, 2018; Steen et al., 2018; Williams et al., 2016). Rather the focus is upon how the five reform narratives portray participation in public service delivery and the extent to which they load it with normative intent, or not.

\section{2 | METHOD}

A systematic literature review was conducted using the PRISMA criteria (Liberati et al., 2009) to explore the following two research questions: how have the most influential PAM reform narratives conceptualised participation; and which factors enable/constrain participation within each narrative. PRISMA study and report eligibility criteria were adopted to support replicability and transparency of the systematic review. To capture studies on participation, keyword searches for the journals below were conducted for the following synonyms: participation, engagement, involvement, collaboration, co-production, and co-creation. The studies included in the review dealt with participation during public service production by a range of actors-citizens, clients, consumers, users and/or customers. The following international peer-reviewed, top-tier PAM journals were included: Public Administration Review, Journal of Public Administration Research and Theory, Public Administration, American Review of Public Administration, Governance, Public Management Review and the Australian Journal of Public Administration. These journals support the inclusion of a breadth of high-quality records, but also yield a manageable number of records for analysis. A snowballing approach was also conducted to supplement the systematic review to include key texts from well-established publishers on the field of PAM (e.g. Routledge and Harvard University Press). Records from earlier NPA scholars, in particular, are in books so this ensured their inclusion. Only written records in English were selected, which is a limitation. Records published between 1968 and 2018 were included to encompass the entire trajectory of the PAM participation literature from NPA onwards. A total of 1356 articles were identified through this search process. They were screened by title and abstract to determine those articles that focused on participation by citizens. This reduced the number of articles to 246 . Further analysis of the full texts was conducted to identify those articles which fell under one of the five narratives above, of which 114 met the selection criteria (the remaining 132 did not make clear references to any of the narratives). These were assessed further to ensure the focus was participation during the service production process rather than policymaking and resulted in the final inclusion of 43 articles. A 


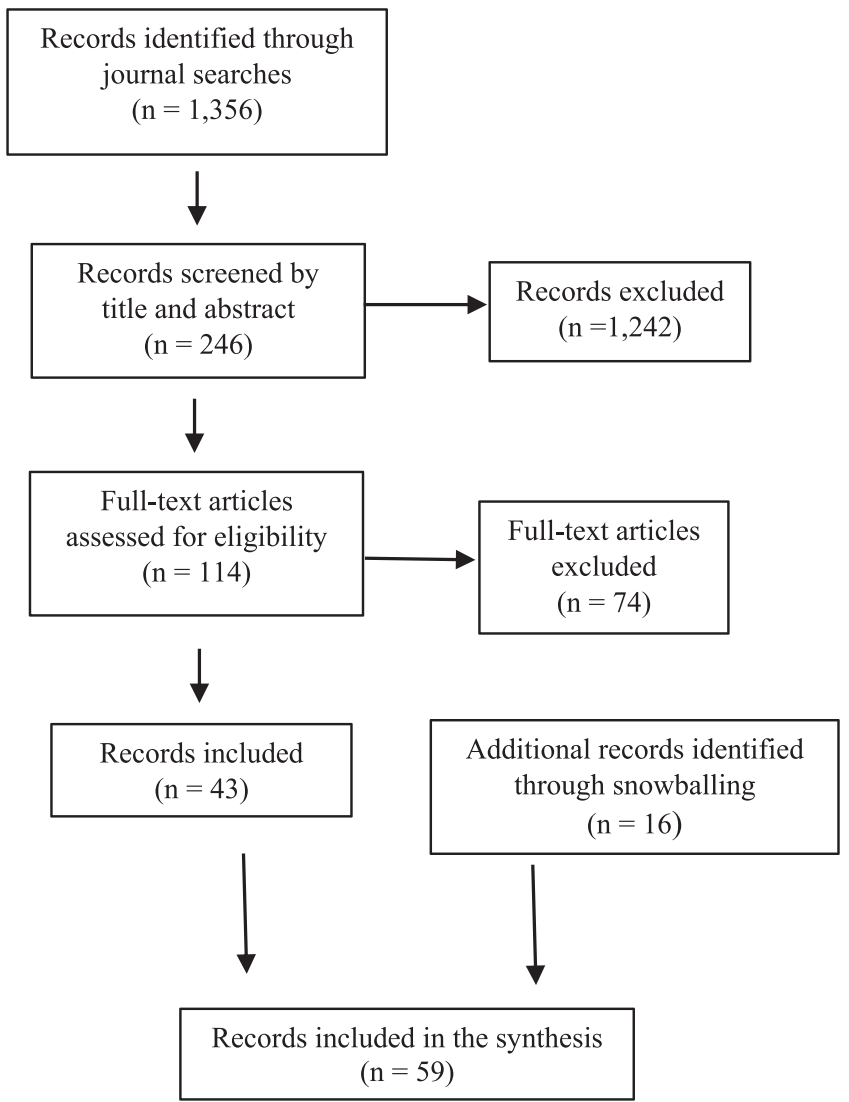

F I G U R 1 Prisma flow chart ournal searches

$(n=1,356)$ 


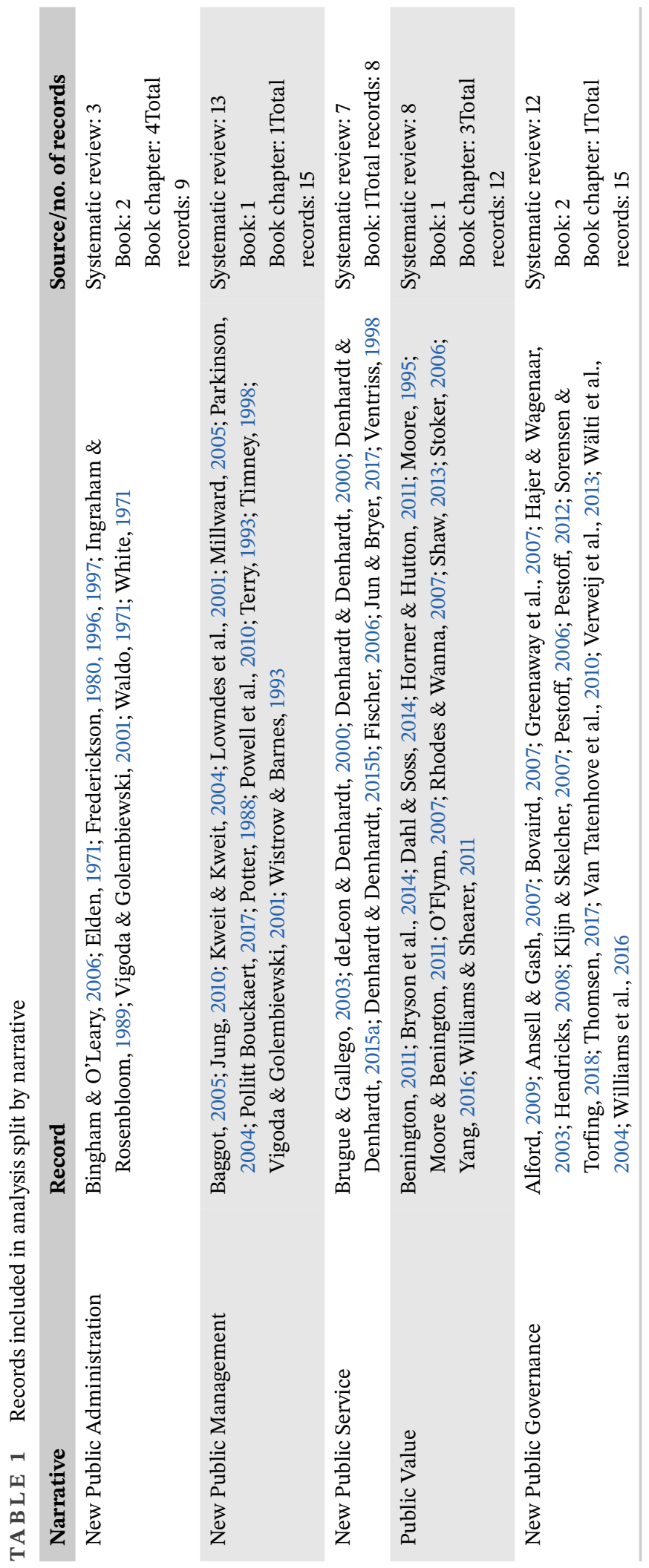


TA B L E 2 Participation within the five narratives

\begin{tabular}{|c|c|c|c|c|c|}
\hline & NPA & NPM & PV & NPS & NPG \\
\hline $\begin{array}{l}\text { Rationale for } \\
\text { participation }\end{array}$ & $\begin{array}{l}\text { Disperse power, } \\
\text { accountability } \\
\text { and legitimacy }\end{array}$ & $\begin{array}{l}\text { Service } \\
\text { improve- } \\
\text { ment and } \\
\text { reduce costs }\end{array}$ & $\begin{array}{l}\text { Creation of } \\
\text { public value } \\
\text { and societal } \\
\text { learning }\end{array}$ & $\begin{array}{l}\text { Democratic } \\
\text { renewal } \\
\text { and } \\
\text { legitimacy }\end{array}$ & $\begin{array}{l}\text { Negotiate } \\
\text { interests } \\
\text { and service } \\
\text { improve- } \\
\text { ment }\end{array}$ \\
\hline $\begin{array}{l}\text { Locus of } \\
\text { participation }\end{array}$ & Political dialogue & $\begin{array}{l}\text { Service } \\
\text { evaluation }\end{array}$ & $\begin{array}{l}\text { Indirect } \\
\text { through } \\
\text { representa- } \\
\text { tive } \\
\text { democracy }\end{array}$ & $\begin{array}{l}\text { Deliberation } \\
\text { during } \\
\text { entire } \\
\text { service } \\
\text { cycle }\end{array}$ & $\begin{array}{l}\text { Inter- } \\
\text { organisational } \\
\text { relation- } \\
\text { ships and } \\
\text { service } \\
\text { delivery }\end{array}$ \\
\hline $\begin{array}{r}\text { Mechanisms of } \\
\text { participation }\end{array}$ & $\begin{array}{c}\text { Decentralisation } \\
\text { and advocacy }\end{array}$ & $\begin{array}{l}\text { Market } \\
\text { mechanisms }\end{array}$ & $\begin{array}{l}\text { Political } \\
\text { deliberation } \\
\text { and } \\
\text { networks. }\end{array}$ & $\begin{array}{l}\text { Active } \\
\text { citizenship } \\
\text { through } \\
\text { deliberation }\end{array}$ & $\begin{array}{l}\text { Networks and } \\
\text { co- } \\
\text { production }\end{array}$ \\
\hline
\end{tabular}

Both NPA and NPS, for example, have embedded a normative approach to participation as a 'good thing'. It is portrayed as addressing the democratic deficit in society and as a counterbalance to the power of social elites and of public service officials (LaPorte, 1971). These two reform discourses come closest to integrating participation in the public policy process together with participation in the delivery of public services. In contrast, NPM has been critiqued for its disregard for citizen and service user participation, except in the narrow economic sense of the self-interested consumer and the promotion of managerialism and consumerism (Christensen \& Laegreid, 2011; Powell et al., 2010). NPG began as an entirely descriptive approach to 'actually existing' public services and the role of citizens in their co-production (Osborne, 2010) and thence developed into a normative theory of Collaborative Governance that has argued for participation as a route to transparent and responsive public services (Sorensen \& Torfing, 2018). Finally, PV has articulated a discourse of participation that situated it as part of networked attempts to enhance the effectiveness of public services through such prescribed mechanisms as consultation processes and formal hearings (Horner \& Hutton, 2011). Table 2 portrays the key dimensions of these five reform narratives and the subsequent analysis discusses them in more detail with reference to their stance on participation.

\section{4 | FIVE PUBLIC SERVICE REFORM STRATEGIES}

\section{1 | New Public Administration}

In reaction to the perceived failings of traditional Public Administration (PA) and especially, the exclusionary effect of remote and disconnected bureaucratic structures (King \& Strivers, 1998), early NPA scholars argued for the restoration of democratic values by placing citizens at the centre of public service decision-making (Elden, 1971; White, 1971). Such participation, especially among disenfranchised communities, was argued normatively as a means of redistributing power to these communities (Waldo, 1971). This aim was to be facilitated predominantly by structural changes, such as decentralisation and delayering (Frederickson, 1996). Framed as an extrinsic process and 
facilitated by public administrators, such participation required the active involvement of civicminded and educated citizens (Frederickson, 1980; Vigoda \& Golembiewski, 2001).

NPA has continued to garner academic interest and critique, particularly in the United States. Although its narrative is still broadly situated in the above ideas, it has been impacted by the subsequent hegemonic influence of NPM (e.g. Vigoda \& Golembiewski, 2001). With social equity as its defining feature, NPA argued against the hegemony of the private sector norms associated with NPM, and towards matters of social justice, fairness and service responsiveness (Frederickson, 1980). The NPA narrative has been criticised for lacking clarity and consensus and has generally been regarded as having had limited impact upon actual public service reform (Denhardt \& Denhardt, 2015a). There is also a lack of empirical evidence explaining how the structural changes proposed by the NPA can enable greater participation or social inclusion. Finally, NPA has been criticised for facilitating the inclusion of educated and articulate citizens and elites, rather than the marginalised groups intended (Ingraham \& Rosenbloom, 1989).

\subsection{New Public Management}

From the 1980s onwards, NPM has developed as the pre-eminent narrative of public service reform. It emerged from critiques of PA strongly linked to a political agenda that involved the privatisation and marketisation of public service provision to 'roll back the state' (Hood et al., 1988). Although NPM's application has varied globally, its main components can be identified as: the privileging of markets as the mechanism through which to coordinate resources with need; output as a key component of legitimacy; a managerial orientation to organisational performance management; the repositioning of citizens as customers/consumers; a preoccupation with performance measurement and management; and the assumed superiority of private sector management techniques (Hood, 1991; Pollitt \& Bouckaert, 2017).

The application of NPM has been widely criticised for its disregard of citizen participation (Christensen \& Laegreid, 2011). The literature suggests two predominant reasons for this. First, the 'managerialism' closely associated with NPM implied closed decision-making (Ansell \& Gash, 2007) by public service managers that overshadowed citizen participation. Rather, the NPM privileged norms of internal organisational efficiency, managerial expertise and performance measurement in public service production (Kweit \& Kweit, 2004). Public managers and/or professionals were cast as powerful protagonists, who possessed the discretion and capacity to catalyse deep transformations (Terry, 1993). NPM thus proposed a linear and closed model of decision-making, which has been criticised for embracing a 'product-dominant logic', likening public services to manufactured goods and viewing production and consumption as discrete processes that function in a sequential and linear value chain (Alford, 2016; Osborne, 2021; Osborne, Nasi, et al., 2021).

Second, NPM has often been associated with consumerism. Categorised as self-interested and passive consumers, the NPM sought to empower citizens through the exercise of individual preferences in the markets/quasi-markets for public services, but not by active participation in the service delivery process. This NPM discourse thus privileged public managers as 'experts', which distinction reinforced existing power asymmetries between such managers and citizens based upon education and expertise (Potter, 1988). Access to information to enable service users to make informed choices, for example, is likely to fall disproportionately to well-educated users and elites, exacerbating inequalities (e.g. Brewis et al., 2021). The consumerism of the NPM has also been 
subject to critique for the atomisation of citizens and undermining of their collective power (Millward, 2005; Powell et al., 2010).

The late 1980s witnessed a range of reforms that tried to marry the citizenship focus of NPA with the consumerist focus of the NPM through, for example, consumer councils, consultation and direct payments (Stewart \& Clarke, 1987). However, in this emergent narrative, participation was typically been framed as an opportunity to reduce costs and increase efficiency rather than to enhance service effectiveness or democracy. Consequently it has been criticised as an appended mechanism of control (Parkinson, 2004; Timney, 1998) or a means of rubber stamping pre-made decisions for the benefit of public officials or local elites rather than a means of igniting a shift in decision-making in favour of citizens (Lowndes et al., 2001).

\section{3 | Public Value}

PV emerged as a challenge to NPM in the 1990s and expressed a more collaborative approach with the intent of creating 'public value'. This term encapsulated the outcomes of public services for society, but was contested both in meaning and application (Shaw, 2013). PV originated with the seminal work of Moore (1995) who developed a normative model of strategic development for public managers that emphasised the pursuit of PV: upwards, towards elected officials to define PV through strategic goals and outcomes, outwards to create an 'authorising environment' among various stakeholders and downwards to develop operational capacity by activating and organising necessary resources, such as staff and technology. PV has subsequently developed into a broad narrative with nuances within it-as a theoretical framework that emphasises public service improvement (Benington, 2011), a management style (Stoker, 2006), a normative narrative (Alford \& O’Flynn, 2009) and/or a governance framework (Bryson et al., 2014).

Despite these variations, participation is a central construct of the PV narrative and is typically offered as a means of addressing the limits of representative democracy (Benington, 2011; Yang, 2016). There is a strong focus in PV on political interaction through networks of deliberation between elected/appointed government officials and civil society to facilitate negotiation, cooperation and decision-making among diverse groups (O'Flynn, 2007). This is operationalised predominantly through formal (e.g. elections, public hearings) and informal (e.g. lobbying, social movements) networks (Bryson et al., 2014). Many PV scholars have also described public service co-production as a core mechanism of citizen participation (Benington, 2011). In practice, however, other more bureaucratic and formal methods of participation have taken a more prominent position, such as consultation, satisfaction surveys and consumer feedback, and which resonate strongly with the NPM narrative (Horner \& Hutton, 2011).

A core criticism of PV is its framing as a polemic against NPM, with limited evidence of its own efficacy (Williams \& Shearer, 2011). PV has failed to counter the closed institutional design of PSOs which forms a substantial barrier to embedding deliberative participation. This is especially so as a result of the formidable power asymmetries both between public service officials and public service users and between social elites and the disenfranchised in society and which typify the delivery of public services (Shaw, 2013). Further, although citizens are described as active, participative and responsible, PV also defines public managers as 'creative entrepreneurs' who translate policy into proposals about what is valuable (Moore \& Benington, 2011) and who, crucially, control the extent of participation, thereby reinforcing traditional power relations (Dahl \& Soss, 2014). Furthermore, like NPA, PV has been reproached for the disproportionate inclusion of organised and articulate elites at the expense of marginal and informal groupings (Williams \& 
Shearer, 2011). Finally, PV has been further criticised for its failure to clearly define value: 'Perhaps the ambiguous nature of $\mathrm{PV}$ and its various applications fuels its popularity-it is all things to all people' (Rhodes \& Wanna, 2007, p. 408; see also O’Flynn, 2021).

\section{4 | New Public Service}

NPS emerged from the United States in the early 2000s, led by the work of Denhardt and Denhardt (2000). It developed from a critique of NPM and a desire to replace market structures, entrepreneurial public managers and self-interest with collaboration through an open and accessible system of governance, within which the citizen becomes central to decision-making throughout the entire public service policy and delivery cycle (Denhardt \& Denhardt, 2000). The NPS is underpinned by three theoretical perspectives: democratic citizenship, which demands greater citizen activeness and a shared vision of 'public interest' (deLeon \& Denhardt, 2000); models of community and civil society, where the government plays a key role in the renewal of civil society; and 'organisational humanism' with a focus on the needs and preferences of citizens, rather than bureaucratic control or objective performance measurements (Denhardt \& Denhardt, 2015b). NPS proposes a 'virtuous circle', where participation is defined as of intrinsic value to citizens and leads to their taking greater civic responsibility-which, in turn, catalyses further participation in public service delivery (Denhardt \& Denhardt, 2015a).

Structural changes have been paramount to the NPS agenda, through new systems of accountability and where active citizenship is institutionalised through the installation of deliberative processes (deLeon \& Denhardt, 2000; Jun \& Bryer, 2017; Ventriss, 1998). Here, the role of government is 'to serve rather than steer'. It acts as the negotiator, enabler and facilitator of collaborative relationships, and public managers play a principal role as 'transformative leaders' (Denhardt \& Denhardt, 2015a; Jun \& Bryer, 2017).

Although the NPS takes a strong normative stance, its arguments for participation have not been substantiated by empirical research. Nor has it offered a substantive solution to the managerial and closed decision-making of the NPM (Osborne, 2021). Its focus on structural changes, for example, suggests an oversimplification of participation in practice, by overlooking the need to carefully organise and facilitate the processes of participation (Fischer, 2006) or to account for the disproportionate influence of social elites. Furthermore, its argument that participation should be institutionalised is challenging because it assumes that all citizens have a latent desire for participation that can be awakened, yet there is a scarcity of evidence to validate this argument (Brugue \& Gallego, 2003).

\subsection{New Public Governance}

Finally, the NPG was first articulated by Osborne (2006) to describe the impact upon PAM of approaches to network governance and collaboration which originated in Europe during the 1990s (Kickert, 1998; Rhodes, 1997). Consequently, NPG built on organisational sociology and network theory to suggest that public management is enacted by networks of actors from the for-profit, public and third sectors (Osborne, 2010). Within the NPG narrative, participation has been framed in two ways. First, 'co-production' has been integrated and repositioned within this narrative. Reconceptualised as co-producers (rather than as consumers, as in the NPM), citizens were here described as working in a horizontal, interactive and co-operative relationship with government 
(Pestoff, 2012). The potential advantages of co-production were discussed widely in the NPG literature, including its potential to increase democracy and tackle challenging social issues (Bovaird, 2007). Second, a new generation of research has repositioned the NPG as a normative framework of 'collaborative governance' (Ansell \& Gash, 2007; Sorensen \& Torfing, 2018). This work has examined the democratic capacity of various actors to work in co-operative relationships to achieve societal consensus. Here, governance networks are typically associated with new systems for autonomous deliberation, negotiation and implementation, and offering their stakeholders innovative structures and spaces of influence. It has been argued to both increase democracy and reduce the cost of public services (Sorensen \& Torfing, 2018).

Although it has been welcomed for involving a plurality of actors, the inclusiveness of NPG has been questioned. Critics have argued that, in practice, network membership was exclusive to those with the necessary organisational infrastructure, expertise, knowledge and skills and who could hence manipulate the system for their own gains (Hendricks, 2008; Van Tatenhove et al., 2010). Indeed, empirical studies have generally suggested that in practice such networks enhanced inter-organisational engagement across PSOs but did not produce greater participation of citizens/communities (Greenaway et al., 2007; Wälti et al., 2004). Legitimacy and accountability have also been raised as concerns. NPG not only added (expensive) complexity to the decisionmaking process (Verweij et al., 2013) but privileged representation through multiple unelected actors/elites (Klijn \& Skelcher, 2007) rather than political representation (Hajer \& Wagenaar, 2003).

Research on the 'dark side' of co-production has also become more prominent in recent years within the NPG (Williams et al., 2016). It has been criticised for its tendency to benefit disproportionately the well-off sections of society and for its confinement to public services that have already been designed by public managers (Thomsen, 2017). It has also been criticised for the control over the provision of opportunities for participation that it cedes to public managers (Alford, 2009). These criticisms raise important questions concerning the extent to which co-production, and the NPG, can lead to genuine citizen participation or whether it is a 'de facto' management tool to retain and strengthen existing managerial and/or elite power.

\section{5 | PARTICIPATION AND PUBLIC SERVICES: AN ALTERNATIVE APPROACH}

As discussed, participation in public service delivery has thus been a recurrent element in the major public service reform narratives since the 1960s, though the motivations behind, processes of, and intended outcomes of it have varied across the five narratives studied here. These have included both expressive and instrumental (Swan \& Combs, 1976) rationales for participation, where it is both an end in its own right and/or a means to achieve more effective public services (e.g. Sorensen \& Torfing, 2018). However, our analysis suggests that in reality citizen participation has remained on the periphery of decision-making structures. The normative stance of some of the narratives is one barrier to its achievement, alongside the hegemony of a linear model of public service delivery, a preoccupation with structural rather than processual change and a failure to address the power imbalances that are endemic to public services. Crucially, four of the narratives discussed above identified participation as something to be 'added into' traditional forms of public service delivery, whereas PV identified it as an outcome of effective public service delivery (Table 1). In reality, however, only limited achievements in user participation in public service delivery have been demonstrated over the last 50 years (Roberts, 2004). Co-production, for 
example, has been positioned in many of these reform narratives as a significant route to the achievement of participation in public service delivery (Nabatchi et al., 2017; Palumbo \& Manesh, 2021). However, iterative studies have identified that co-production, in isolation, is itself subject to the systemic problems of power asymmetry and elite capture identified above (Farr, 2018; Flemig \& Osborne, 2019; Williams et al., 2016).

To counter these limitations, we argue for an approach to public service reform that builds on and integrates the extrinsic forms of participation discussed above, but which also draws upon the unique insights of service management and marketing (SM\&M) theory to understand the intrinsic modes of participation which characterise services. This approach is an evolving one in the PAM literature (e.g. Alford, 2016; Dudau et al., 2019; Engen et al., 2021; Hodgkinson et al., 2017) and which has become known latterly as Public Service Logic (PSL) (Osborne, 2021; Osborne, Nasi, et al., 2021). It is also one which arguably offers a public service reform framework that has participation at its centre rather than periphery.

Such an approach to participation in public service delivery has seven distinct features. First, it appreciates that public services are a concrete expression of extant societal values and that participation needs to be understood within this values-based framework (Flinders et al., 2016). In the discussion above, the NPS, for example, is situated within a values-framework that seeks to address the 'democratic deficit' through active citizenship (Denhardt \& Denhardt, 2015a). By contrast, NPM is situated in one that privileges the market as hegemonic in society and where participation is a route to cost reduction within such markets/quasi-markets (Fotaki, 2015). Such societal values will shape the nature of participation in public service delivery. Public managers cannot shape such societal and political values but they do need to understand and respond to them, as the PV discourse has appreciated. PSL situates such values within the societal service ecosystem that is the context for citizen participation in public service delivery (Petrescu, 2019; Strokosch \& Osborne, 2020a).

Second, and linked to the above, PSL argues that the delivery of public services is not a linear production process of the turning of inputs into outputs, nor is it the sole responsibility of public managers. Rather it is a complex and interactive space where both citizens and public service users interact with societal values and norms, PSOs, the local community and service delivery processes. This complexity is captured through the metaphor of public service ecosystems (Strokosch \& Osborne, 2020a). Hence, participation has to be situated within such ecosystems. Responsive public service delivery is thus not a matter of internal efficacy alone or dependent on the singlehanded transformative capacity of public managers as often articulated in the above reform narratives, as Pollitt and Boukaert (2017) have noted. Rather it is a dynamic process of interaction, negotiation and co-operation between multiple actors, including citizens, and other resources at various levels of the system (Skålén et al., 2015). Citizen participation, therefore, needs to be understood within these complex and dynamic public service ecosystems, instead of focusing predominantly on the structural features of public service delivery and reform (Kinder et al., 2021; Leite \& Hodgkinson, 2021). The former stresses the centrality of participation to public service delivery, whereas the latter continues to articulate it as an 'add-on' to service delivery processes.

Third, recent innovations in SM\&M theory have moved to identify participation as a core, inalienable, element of service usage and value creation (Vargo \& Lusch, 2008). Such participation is a crucial determinant of the value that a user derives from a service: the actual experience of participation creates expressive value for the service user as well as creating instrumental value in relation to their needs. This value can be expressed both as value-in-use (based on the public service experience) and as value-in-context (based upon its relationship to the needs and expectations of the public service user) (Grönroos, 2019). Further, SM\&M theory sees no conflict between 
instrumental and expressive value creation-both are central to the creation of value for the service user (Hardyman et al., 2015, 2019). The day-to-day experience of a school pupil is, for example, as important to their well-being and welfare (and needs) as is their academic attainment.

Fourth, participation is an intrinsic element that is fundamental to the production of public services 'as services' (Osborne, 2021). It is not something to be 'added into' service delivery but rather an element of the process that has to be governed and worked with by service providers-it cannot be avoided (Grönroos \& Voima, 2013). Intrinsic processes of participation will thus shape the nature of the public service by bringing the expectations, experiences and needs of the user into the service delivery process. Public services will also shape the public service user's wholelife experience, by the way in which the experience of receiving a service affects their immediate personal well-being and their future expectations of their capacity in society. Value, from this perspective, is socially constructed, both on the basis of service users' subjective interpretations of the service during use and by its shared experience within their social context (i.e. with family, friends, other service users) (Eriksson \& Nordgren, 2018). Positioning public service users and their 'lived experience' of a service as a defining dimension of its delivery reframes their role from passive consumer or 'lay person' who is acted upon, to active service producer and value creator (Grönroos \& Voima, 2013). In contrast to the previous narratives, PSL thus understands public service users as integral actors who are instrumental to the realisation of their own needs. The core task of public management is thus to facilitate and support this 'actually existing' participation, rather than to create, ignore or undermine it.

Fifth, participation can also be extrinsic to public service delivery, as articulated within the PAM discourse discussed above. In this case, it can be consciously added into public service delivery through co-design and co-production (Bason, 2017; Bason \& Austin, 2021; Haustein \& Lorsen, 2021; Trischler \& Westwood-Trischler, 2021). This has been expressed as creating valuein-production as a function of participation in public service delivery (Osborne, Nasi, et al., 2021). However, the extrinsic processes of participation endorsed by the previous narratives have, to date, been insufficiently persuasive in re-orientating away from NPM's unprecedented emphasis on internal organisational efficacy at the expense of collectively-held PVs (Nabatchi, 2018). By emphasising the complexity rather than the linearity of the public service production process and the intrinsic processes of participation, PSL supports a deeper re-orientation towards the valuesbased framework centred on the user and societal needs it reflects.

Sixth, participation has import for multiple actors in the public service ecosystem, not only the identified service user. Of course, this user is a key actor and can accrue value in their own lives from a public service. However, citizens who are not users of a public service can also accrue value. This can be individual value, perhaps through a role as a volunteer or carer in a public service, but it can also be through the way that participation in public service delivery enables societal value, such as social inclusion or environmental enhancement (Musso et al., 2019). Needless to say, individual and societal value are not always congruent and can sometimes conflict (Benington, 2011). Further, even individuals who are not citizens can accrue value through participation in public service delivery—such as tourists (Soszynski et al., 2018) or asylum seekers (Strokosch \& Osborne, 2016).

Seventh, participation is not a zero-sum game for public services. It is as possible to destroy individual and societal value through participation as to create it (Palumbo, 2017). The service user can destroy value when they refuse to participate according to procedures/rules established by the PSO. This might, for example, be by not following a treatment plan designed with their doctor (destruction of individual value) or by refusing to follow the rules for household recycling and/or by sabotaging those rules by fly-tipping (destruction of societal value). It can also be destroyed by 
a failure of the interaction between the public service user and public officials (e.g. the breakdown of trust between a patient and their doctor where treatment proves problematic).

\section{6 | CONCLUSIONS: ENACTING A VALUE-CREATION FRAMEWORK FOR PARTICIPATION IN THE DELIVERY OF PUBLIC SERVICES}

The preceding discussion has explored how participation has been framed and evolved within the five most influential narratives of public service reform. An alternative narrative has subsequently been proposed. This integrates insights from PAM and SM\&M to emphasise participation as a core component of public service delivery and which offers important implications for PAM theory and practice.

\section{1 | Implications for theory}

By centring on the creation of user and societal value through the use of public services rather than the production of public services, this paper has offered a novel view of citizen participation that is embedded in the reality of public service delivery and that acknowledges both its expressive and instrumental potential for creating (or destroying) value. It also shifts the role of the public service users, including their needs, experiences and expectations, from the periphery to the heart of public service delivery. This marks an important departure in theorising about participation in public services, where the transformative potential of public managers, professionals and the stakeholder elite has traditionally been the emphasis. This is not to say that public service officials are unimportant or irrelevant. They are not-they have a key role to play. However, this role is predicated upon the value creation and co-creation activities of public service users and citizensrather than vice versa. This latter element is the mainspring of participation and gives it a context and meaning.

To fully realise the potential for PAM theory of the value-creation approach to participation articulated here, it is necessary to address three key challenges. First, the intrinsic and extrinsic processes of value creation imply the skills and capacity of public service staff to understand and facilitate them. It is not so much a question of 'how to enable participation', but rather 'how to maximise the positive effects of the naturally occurring participation'. Such an approach is at odds with the product-dominant one that characterises the prevailing NPM narrative and which posits participation as an add-on and constrained outcome rather than an intrinsic element of public service delivery (Loeffler \& Bovaird, 2016). This requires the evolution of theory by the integration of SM\&M insights into PAM. This evolution has already commenced (e.g. Eriksson, 2019; Skålén et al., 2018) and this paper is a contribution to it.

Second, a value-creation approach to participation does not deny the challenges of enabling the extrinsic participative processes of public service delivery, as delineated above. The tensions of extrinsic participation common to the five discourses of public service reform discussed previously remain, particularly in terms of professional opposition to user-led services and partial or cosmetic forms of participation, the impact of professional power, and the skewing effect of elite capture of public services. This is the contribution of PAM to our framework. Iterative waves of structural reforms have not been sufficient in overcoming these obstacles for public services, suggesting that enabling extrinsic forms of participation is dependent rather upon deeper cultural and strategic orientation changes for PSOs that seek to shift rather than ameliorate these 
structural and power imbalances (Osborne et al., 2020). This is a challenging task but not impossible (Grönroos, 2019). Third, a value-creation approach to participation privileges working at the public service ecosystem level rather than focusing either upon the individual service user, the citizen, or the PSO alone. The dynamic interaction of the actors, structures and processes within such ecosystems is central both to the effective governance of participation in public service delivery and to its contribution to the creation rather than destruction of individual and societal value (Osborne, Powell, et al., 2021; Petrescu, 2019). This requires further empirical investigation and theoretical exposition.

\section{2 | Implications for practice}

The alternate approach to participation presented here has four important implications for public service management in practice. First, the effective management of public services by public service managers and professional staff requires an appreciation of the intrinsic processes of participation within the delivery of these services and the fundamental role of public service users during these processes. It requires to be consciously engaged with rather than allowing it to impact upon public service outcomes and value creation by default. Second, a pragmatic and sensitive approach to extrinsic forms of participation is necessary that links the application of co-production and codesign in public service delivery to the individual and societal context of the needs that these services address. This is a task for both politicians and public service officials. Third, value-creation through services can often require public service practitioners to balance value creation across different service users and stakeholders and/or between individual and societal value. This has significant implications for the role of participation, both intrinsic and extrinsic, in public service delivery. Finally, embedding value creation and its associated participative processes within public policy and public service management through cultural change is necessary to support the creation of value. As noted, such cultural change is a difficult and complex process to achieve and needs clear and unequivocal senior management leadership and support (Baggot, 2005; Karp \& Helg, 2008). However, it is not impossible (Grönroos, 2019). Further, such cultural change will need to address the endemic power imbalances discussed previously (Farr, 2018).

\subsection{Implications for future research}

This paper argues for the combinatory evolution of our understanding of participation in public services, through the integration of insights from SM\&M and PAM theory. We end by arguing for an emerging research agenda around a value-creation framework for participation in public services, with seven clear research themes. First, the concepts of value and value creation in public services need to be more clearly defined, conceptualised and validated by empirical research. This would include an examination of the different dimensions of such value, how these might be differentiated and understood by various stakeholders and an examination of potential value conflicts and how these might be resolved (Scarli, 2021). Second, the operationalisation of value creation in the service user sphere requires more detailed exploration, with particular attention to the impact of value creation processes upon user participation and vice versa. It also requires the exploration of the impact of the wider public service ecosystem upon participation.

Third, the four intrinsic and extrinsic processes of participation identified and differentiated above require further investigation. This would include an examination of their enablers, risks 
and barriers, as well as their implications for value creation/destruction. Fourth, despite the vast literature on participation, challenging questions remain around how to embed sustainable participative structures and processes within both PSOs and public service ecosystems, to address both the dominant cultural, political, and power dimensions and the potential subversive impact of social elites identified above (Yang, 2016). The approach articulated here suggests that the intrinsic processes of public service delivery have the potential to moderate and mediate the power between public service officials and service users-but that this needs to be weighed against the impact of the extrinsic forms of participation and their potential for dominance by public service officials and by social elites. These processes also need situating within the broader public service ecosystem and its implications for the achievement and impact of participation in public service delivery.

Fifth, as noted at the outset, this analysis has been at the level of public service reform discourses. Further detailed empirical work of the links between value creation and participation is required in specific public service contexts, in order to explore the complexity and nuances of it. Sixth, evaluation of specific mechanisms of citizen participation (e,g, participatory budgeting and/or volunteering), and their implication for a value creation approach to participation, is required (Manes-Rossi et al., 2021). Finally, further work is required that examines the nexus between participation discourses in relation to political discourse, public policymaking and public service delivery. Greater relief is needed in understanding how these discourses interact, or not, and their impact upon each other.

\section{ACKNOWLEDGEMENTS}

This project received funding from the European Union's Horizon 2020 research and innovation programme under grant agreement no. 770356. This publication reflects the views only of the author, and the agency cannot be held responsible for any use that may be made of the information contained therein.

\section{O R C I D}

Kirsty Strokosch (D) https://orcid.org/0000-0001-6119-2112

\section{REFERENCES}

Alford, J. (2009). Engaging public sector clients: From service-delivery to co-production. Palgrave Macmillan.

Alford, J. (2016). Co-production, interdependence and publicness: Extending public service dominant logic. Public Management Review, 18(5), 673-691.

Alford, R., \& Friedland, R. (1975). Political participation and public policy. Annual Review of Sociology, 1, 429-479.

Alford, J., \& O’Flynn, J. (2009). Making sense of Public Value: Concepts, critiques and emergent meanings. International Journal of Public Administration, 32, 171-191.

Ansell, C., \& Gash, A. (2007). Collaborative governance in theory and practice. Journal of Public Administration Research and Theory, 18, 543-571.

Baggot, R. (2005). A funny thing happened on the way to the forum? Reforming patient and public involvement in the NHS in England. Public Administration, 83(3), 533-551.

Bason, C. (2017). Leading public design: Discovering human-centred governance. Policy Press.

Bason, C., \& Austin, R. (2021). Design in the public sector: Toward a human centred model of public governance. Public Management Review. https://doi.org/10.1080/14719037.2021.1919186

Benington, J. (2011). From private choice to public value. In J. Benington \& M. Moore (Eds.), Public value: Theory and practice (pp. 31-49). Palgrave MacMillan.

Bingham, L., \& O’Leary, R. (2006). Conclusion: Parallel play, not collaboration: Missing questions, missing connections. Public Administration Review, 66(S1), 161-167. 
Bovaird, T. (2007). Beyond engagement and participation - User and community co-production of public services. Public Administration Review, 67, 846-860.

Brewis, A., Meehan, K., Beresford, M., \& Wutich, A. (2021). Anticipating elite capture: The social devaluation of municipal tap water users in the Phoenix metropolitan area. Water International, 46(6), 821-840. https://doi. org/10.1080/02508060.2021.1898765

Brugue, Q., \& Gallego, R. (2003). A democratic public administration? Developments in public participation and innovations in community governance. Public Management Review, 5(3), 425-447.

Bryson, J. M., Crosby, B. C., \& Bloomberg, L. (2014). Public value governance: Moving beyond traditional Public Administration and the New Public Management. Public Administration Review, 74(4), 445-456.

Christensen, T., \& Laegreid, P. (2011). Democracy and administrative policy: Contrasting elements of New Public Management (NPM) and post-NPM. European Policy Science Review, 3(1), 125-146.

Dahl, A., \& Soss, J. (2014). Neoliberalism for the common good? Public Value Governance and the downsizing of democracy. Public Administration Review, 74(4), 496-504.

deLeon, L., \& Denhardt, R. B. (2000). The political theory of reinvention. Public Administration Review, 60(2), 89-97.

Denhardt, R. B., \& Denhardt, J. V. (2000). The New Public Service: Serving rather than steering. Public Administration Review, 60(6), 549-559.

Denhardt, J. V., \& Denhardt, R. B. (2015a). New Public Service: Serving, not steering (4th ed.). Routledge.

Denhardt, J. V., \& Denhardt, R. B. (2015b). The new public service revisited. Public Administration Review, 75(5), 664-672.

Dudau, A., Glennon, R., \& Verschuere, B. (2019). Following the yellow brick road?(Dis) enchantment with codesign, co-production and value co-creation in public services. Public Management Review, 21(11), $1577-1594$.

Elden, J. M. (1971). Radical politics and the future of public administration in the postindustrial era. In D. Waldo (Ed.), Public administration in a time of turbulence (pp. 19-42). Scranton.

Engen, M., Fransson, M., Quist, J., \& Skålén, P. (2021). Continuing the development of the public service logic. Public Management Review, 23(6), 886-905.

Eriksson, E. M. (2019). Representative co-production: Broadening the scope of the public service logic. Public Management Review, 21(2), 291-314.

Eriksson, E. M., \& Nordgren, L. (2018). From one-sized to over-individualized? Service logic's value creation. Journal of health Organization and Management, 32(4), 572-586.

Farr, M. (2018). Power dynamics and collaborative mechanisms in co-production and co-design processes. Critical Social Policy, 38(4), 623-644.

Fischer, F. (2006). Participatory governance as deliberative empowerment: The cultural politics of discursive space. The American Review of Public Administration, 36(1), 19-40.

Flemig, S. S., \& Osborne, S. (2019). The dynamics of co-production in the context of social care personalisation: Testing theory and practice in a Scottish context. Journal of Social Policy, 48(4), 671-697.

Flinders, M., Wood, M., \& Cunningham, M. (2016). The politics of co-production: Risks, limits and pollution. Evidence \& Policy: A Journal of Research, Debate and Practice, 12(2), 261-279.

Fotaki, M. (2015). Co-production under the financial crisis and austerity: A means of democratizing public services or a race to the bottom? Journal of Management Enquiry, 24(4), 433-438.

Frederickson, H. G. (1980). The New Public Administration. University of Alabama Press.

Frederickson, H. G. (1996). Comparing the reinventing government movement with the new public administration. Public Administration Review, 56(3), 263-270.

Frederickson, H. G. (1997). The spirit of public administration. Jossey-Bass.

Greenaway, J., Salter, B., \& Hart, S. (2007). How policy networks can damage democratic health: A case study in the government of governance. Public Administration, 85(3), 717-738.

Grönroos, C. (2019). Reforming public services: Does service logic have anything to offer? Public Management Review, 21(5), 775-788.

Grönroos, C., \& Voima, P. (2013). Critical service logic: Making sense of value creation and co-creation. Journal of the Academy of Marketing Science, 41(2), 133-150.

Hajer, M., \& Wagenaar, H. (2003). Deliberative policy analysis: Understanding governance in the network society. Cambridge University Press.

Hardyman, W., Daunt, K. L., \& Kitchener, M. (2015). Value co-creation through patient engagement in health care: A micro-level approach and research agenda. Public Management Review, 17(1), 90-107. 
Hardyman, W., Kitchener, M., \& Daunt, K. L. (2019). What matters for me! User conceptions of value in specialist cancer care. Public Management Review, 21(11), 1687-1706.

Haustein, E., \& Lorsen, P. (2021). Co-creation and co-production in municipal risk governance - A case study of citizen participation in a German city. Public Management Review. https://doi.org/10.1080/14719037.2021.1972704

Hendricks, C. M. (2008). On inclusion and network governance: The democratic disconnect of Dutch energy transitions. Public Administration, 86(4), 1009-1031.

Hirschman, A. O. (1970). Exit, voice and loyalty: Responses to decline in firms, organizations and states. Harvard University Press.

Hodgkinson, I., Hannibal, C., Keating, B., Chester-Buxton, R., \& Bateman, N. (2017). Towards a public service management. Journal of Service Management, 28(5), 998-1023.

Hood, C. (1991). A public management for all seasons? Public Administration, 63, 3-19.

Hood, C., Dunsire, A., \& Thomson, L. (1988). Rolling back the state: Thatcherism, Fraserism and bureaucracy. Governance, 1(3), 243-270.

Horner, L., \& Hutton, W. (2011). Public value, deliberative democracy and the role of public managers. In J. Benington \& M. Moore (Eds.), Public value: Theory and practice (pp. 112-126). Palgrave Macmillan.

Ingraham, P., \& Rosenbloom, D. H. (1989). The new public personnel and the new public service. Public Administration Review, 49(2), 115-126.

Jun, K. N., \& Bryer, T. (2017). Facilitating public participation in Local Governments in hard times. American Review of Public Administration, 47(7), 840-856.

Jung, T. (2010). Citizens, co-producers, customers, clients, captives? A critical review of consumerism and public services. Public Management Review, 12(3), 439-466.

Karp, T., \& Helg, T. (2008). From change management to change leadership: Embracing chaotic change in public service organizations. Journal of Change Management, 8(1), 85-96.

Kickert, W. (1998). Public management and administrative reform in Western Europe. Elgar.

Kinder, T., Stenvall, J., Six, F., \& Memon, A. (2021). Relational leadership in collaborative governance ecosystems. Public Management Review, 23(11), 1612-1639. https://doi.org/10.1080/14719037.2021.1879913

King, C. S., \& Strivers, C. (1998). Government is us: Public administration in an anti-government era. Sage.

Klijn, E. H., \& Skelcher, C. (2007). Democracy and governance networks: Comparable or not? Public Administration, 85(3), 587-608.

Kweit, M. G., \& Kweit, R. W. (2004). Citizen participation and citizen evaluation in disaster recovery. American Review of Public Administration, 34(4), 354-373.

LaPorte, T. (1971). The recovery of relevance in the study of public administration. In F. Marini (Ed.), Toward a new public administration: The Minnowbrook perspective (pp. 17-48). Chandler.

Leite, H., \& Hodgkinson, I. (2021). Examining resilience across a service ecosystem under crisis. Public Management Review. https://doi.org/10.1080/14719037.2021.2012375

Liberati, A., Altman, D. G., Tetslkaff, J., Mulrow, C., Gotzsche, P. C., Ioannidis, J. P. A., Clarke, M., Devereaux, P. J., Kleijnen, J., \& Moher, D. (2009). The PRISMA statement for reporting systematic reviews and meta-analyses of studies that evaluate health care interventions: Explanation and elaboration. Journal of Clinical Epidemiology, 62(10), e1-e34.

Loeffler, E., \& Bovaird, T. (2016). User and community co-production of public services: What does the evidence tell us? International Journal of Public Administration, 39(13), 1006-1019.

Lowndes, V., Pratchett, L., \& Stoker, G. (2001). Trends in public participation: Part I - Local government perspectives. Public Administration, 79(1), 205-222.

Manes-Rossi, F., Brusca, I., Levy Orelli, R., Lorson, P., \& Haustein, E. (2021). Features and drivers of citizen participation: Insights from participatory budgeting in three European cities. Public Management Review. https://doi.org/10.1080/14719037.2021.1963821

Michels, A., \& de Graf, L. (2010). Examining citizen participation: Local participatory policy making and democracy. Local Government Studies, 36(4), 477-491.

Millward, L. (2005). 'Just because we are amateurs doesn't mean we aren't professional': The importance of expert activists in tenant participation. Public Administration, 83(3), 735-751.

Moore, M. (1995). Creating public value: Strategic management in government. Harvard University Press.

Moore, M., \& Benington, J. (2011). Conclusions: Looking ahead. In J. Benington \& M. Moore (Eds.), Public value: Theory and practice (pp. 256-274). Palgrave MacMillan. 
Musso, J., Young, M., \& Thom, M. (2019). Volunteerism as co-production in public service management. Public Management Review, 21(4), 473-494.

Nabatchi, T. (2018). Public values frames in administration and governance. Perspectives on Public Management and Governance, 1(1), 59-72.

Nabatchi, T., Sancino, A., \& Sicilia, M. (2017). Varieties of participation in public services: The who, when, and what of coproduction. Public Administration Review, 77(5), 766-776.

O’Flynn, J. (2007). From New Public Management to Public Value: Framework change and managerial implications. The Australian Journal of Public Administration, 66(3), 353-366.

O’Flynn, J. (2021). Where to for public value?' International Journal of Public Administration, 44(10), 867-877. https://doi.org/10.1080/01900692.2021.1884696

Osborne, S. (2006). The New Public Governance? Public Management Review, 8(3), 377-388.

Osborne, S. (2010). The New Public Governance?. Routledge.

Osborne, S. (2021). Public Service Logic. Routledge.

Osborne, S., Cucciniello, M., Strokosch, K., \& Nasi, G. (2020). Strategic user orientation in public services deliveryThe missing link in the strategic trinity? Public Money \& Management, 41(2), 172-175.

Osborne, S., Powell, M., Cui, T., \& Strokosch, K. (2021). Appreciate - Engage - Facilitate': The role of public managers in value creation in public service ecosystems. Public Money \& Management, 41(8), 668-671. https://doi.org/10.1080/09540962.2021.1916189

Osborne, S., Nasi, G., \& Powell, M. (2021). Beyond co-production: Value co-creation in public services. Public Administration, 99(4), 641-657.

Palumbo, R. (2017). The bright side and the dark side of patient empowerment: Co-creation and co-destruction of value in the healthcare environment. Springer.

Palumbo, R., \& Manesh, M. F. (2021). Travelling along the public service co-production road: A bibliometric analysis and interpretive review. Public Management Review. https://doi.org/10.1080/14719037.2021.2015222

Parkinson, J. (2004). Why deliberate? The encounter between deliberation and new public managers. Public Administration, 82(2), 377-395.

Pestoff, V. (2006). Citizens and co-production of welfare services. Public Management Review, 8(4), 503-519.

Pestoff, V. (2012). New Public Governance, co-production and third sector social services in Europe: Crowding in and crowding out. In V. Pestoff, T. Brandsen, \& B. Verschuere (Eds.), New Public Governance, the third sector and co-production (pp. 13-34). Routledge.

Pestoff, V. (2014). Collective action and the sustainability of co-production. Public Management Review, 16(3), 383401.

Pollitt, C., \& Bouckaert, G. (2017). Public management reform: A comparative analysis. Oxford University Press.

Potter, J. (1988). Consumerism and the public sector: How well does the coat fit? Public Administration, 66, 149-164.

Powell, M., Greener, I., Szmigin, I., Doheny, S., \& Mills, N. (2010). Broadening the focus of public service consumerism. Public Management Review, 12(3), 323-339.

Petrescu, M. (2019). From marketing to public value: Towards a theory of public service ecosystems. Public Management Review, 21(11), 1733-1752.

Rhodes, R. A. W. (1997). Understanding governance: Policy networks, governance, reflexivity and accountability. Open University Press.

Roberts, N. (2004). Public deliberation in an age of direct citizen participation. American Review of Public Administration, 34(4), 315-353.

Rhodes, R. A. W., \& Wanna, J. (2007). The limits to Public Value, or rescuing responsible government from the Platonic Guardians. The Australian Journal of Public Administration, 66(4), 406-421.

Scarli, J. (2021). Responsibilization and value conflicts in healthcare co-creation: A public service logic perspective. Public Management Review. https://doi.org/10.1080/14719037.2021.2013070

Shaw, R. (2013). Another size fits all? Public value management and challenges or institutional design. Public Management Review, 15(4), 477-500.

Shoemaker, P., Tankard, J., \& Lasorsa, D. (2004). How to build social science theories. Sage.

Skålén, P., Pace, S., \& Cova, B. (2015). Firm-brand community value co-creation as alignment of practices. European Journal of Marketing, 49(3/4), 596-620.

Skålén, P., Karlsson, J., Engen, M., \& Magnuson, P. R. (2018). Understanding public service innovation as resource integration and creation of value propositions. Australian Journal of Public Administration, 77(4), $700-714$. 
Sorensen, E., \& Torfing, J. (2018). The democratizing impact of governance networks: From pluralisation, via democratic anchorage, to interactive political leadership. Public Administration, 96(2), 302-317.

Soszyński, D., Sowińska-Świerkosz, B., Stokowski, P. A., \& Tucki, A. (2018). Spatial arrangements of tourist villages: Implications for the integration of residents and tourists. Tourism Geographies, 20(5), 770-790.

Steen, T., Brandsen, T., \& Verscheure, B. (2018). The dark sides of co-creation and co-production: Seven evils. In T Brandsen, T Steen, \& B Verscheure (Eds.), Co-production and co-creation - Engaging citizens in public services (pp. 284-293). Routledge.

Stewart, J., \& Clarke, M. (1987). The public service orientation: Issues and dilemmas. Public Administration, 65(2), 161-177.

Stoker, G. (2006). Public Value Management: A new narrative for networked governance? American Review of Public Administration, 36(1), 41-57.

Strokosch, K., \& Osborne, S. (2016). Asylum seekers and the co-production of public services: Understanding the implications for social inclusion and citizenship. Journal of Social Policy, 45(4), 673-690.

Strokosch, K., \& Osborne, S. (2020a). Co-experience, co-production and co-governance: An ecosystem approach to the analysis of value creation. Policy \& Politics, 48(3), 425-442.

Strokosch, K., \& Osborne, S. (2020b). If citizen participation is so important, why has it not been achieved?' Public Money \& Management, 40(1), 8-10.

Swan, J. E., \& Combs, L. J. (1976). Product performance and consumer satisfaction: A new concept. Journal of Marketing, 40(2), 25-33.

Terry, L. D. (1993). Why we should abandon the misconceived quest to reconcile public entrepreneurship with democracy. Public Administration Review, 53(4), 393-395.

Thomsen, M. K. (2017). Citizen co-production: The influence of self-efficacy perception and knowledge of how to co-produce. American Review of Public Administration, 47(3), 340-353.

Timney, M. M. (1998). Overcoming administrative barriers to citizen participation: Citizens as partners, not adversaries. In C. S. King \& C. Strivers (Eds.), Government is us: Public administration in an anti-government era (pp. 88-101). Sage.

Trischler, J., \& Westman-Trischler, J. (2021). Design for experience - A public service design approach in the age of digitalization. Public Management Review. https://doi.org/10.1080/14719037.2021.1899272

Turnhout, E., Metze, T., Wyborn, C., Klenk, N., \& Louder, E. (2020). The politics of co-production: Participation, power, and transformation. Current Opinion in Environmental Sustainability, (42) 15-21.

Van Tatenhove, J., Edelenbos, J., \& Klok, P. J. (2010). Power and interactive policy-making: A comparative study of power and influence in eight interactive projects in the Netherlands. Public Administration, 88(3), 609-626.

Vargo, S. L., \& Lusch, R. F. (2008). Service-dominant logic: Continuing the evolution. Journal of the Academy of Marketing Science, 36(1), 1-10.

Vigoda, E., \& Golembiewski, R. T. (2001). Citizenship behavior and the spirit of new managerialism - A theoretical framework and challenge for governance. American Review of Public Administration, 31(3), 273-295.

Ventriss, C. (1998). Radical democratic thought and contemporary American public administration: A substantive perspective. American Review of Public Administration, 28(3), 227-245.

Verweij, S., Klijn, E. H., Edelenbos, J., \& Van Buuren, A. (2013). What makes governance networks work? Public Administration, 91(4), 1035-1055.

Waldo, D. (1971). Some thoughts on alternatives, dilemmas, and paradoxes in a time of turbulence. In D. Waldo (Ed.), Public administration in a time of turbulence (pp. 257-286). Scranton.

Wälti, S., Küjbler, D., \& Papadopoulos, Y. (2004). How democratic is "governance”? Lessons from Swiss drug policy. Governance, 17(1), 83-113.

White, O. (1971). Social change and administrative adaptation. In F. Marini (Ed.), Toward a new public administration: The Minnowbrook perspective (pp. 59-67). Chandler.

Williams, I., \& Shearer, H. (2011). Appraising Public Value: Past, present and futures. Public Administration, 89(4), 1367-1384.

Williams, B. N., Kang, S. C., \& Johnson, J. (2016). (Co)-contamination as the dark side of co-production: Public value failures in co-production processes. Public Management Review, 18(5), 692-717.

Wirtz, B., Weyerer, J., \& Rösch, M. (2019). Open government and citizen participation: An empirical analysis of citizen expectancy towards open government data. International Review of Administrative Sciences, 85(3), 566586 
Wistrow, G., \& Barnes, M. (1993). User involvement in community care: Origins, purposes and applications. Public Administration, 71, 271-299.

Yang, K. (2016). Creating public value and institutional innovations across boundaries: An integrative process of participation, legitimation and implementation. Public Administration Review, 76(6), 873-885.

How to cite this article: Osborne, S. P., \& Strokosch, K. (2022). Participation: Add-on or core component of public service delivery? Aust J Publ Admin, 1-20.

https://doi.org/10.1111/1467-8500.12536 